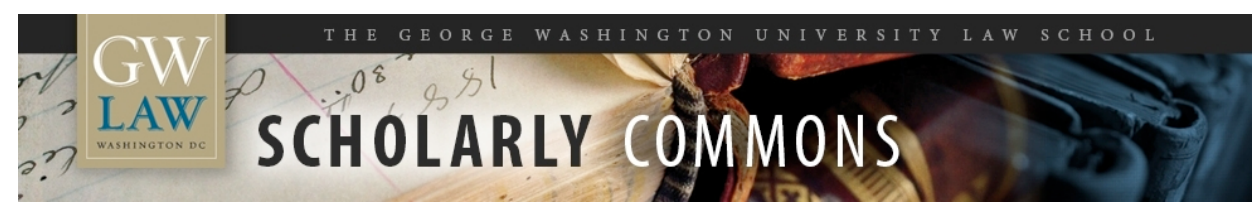

\title{
Denying the Significance of Race
}

Cynthia Lee

George Washington University Law School, cylee@law.gwu.edu

Follow this and additional works at: https://scholarship.law.gwu.edu/faculty_publications

Part of the Law Commons

\section{Recommended Citation}

Lee, Cynthia, Denying the Significance of Race (2014). Denying the Significance of Race: Colorblindness and the Zimmerman Trial in Trayvon Martin, Race, and American Justice 31 (Kenneth J. Fasching-Varner, et al. eds., 2014); GWU Law School Public Law Research Paper No. 2017-62; GWU Legal Studies Research Paper No. 2017-62. Available at SSRN: http://ssrn.com/abstract=3026382

This Chapter is brought to you for free and open access by the Faculty Scholarship at Scholarly Commons. It has been accepted for inclusion in GW Law Faculty Publications \& Other Works by an authorized administrator of Scholarly Commons. For more information, please contact spagel@law.gwu.edu. 


T E A C H I N G R A C E A N D E T H N I C I T Y

\section{Trayvon Martin, Race, and American Justice}

Writing Wrong

Kenneth J. Fasching-Varner,

Rema E. Reynolds, Katrice A. Albert and Lori L. Martin (Eds.)

Foreword by Tyrone Howard

SensePublishers 
A C.I.P. record for this book is available from the Library of Congress.

ISBN: 978-94-6209-840-4 (paperback)

ISBN: 978-94-6209-841-1 (hardback)

ISBN: 978-94-6209-842-8 (e-book)

Published by: Sense Publishers,

P.O. Box 21858,

3001 AW Rotterdam,

The Netherlands

https://www.sensepublishers.com/

Printed on acid-free paper

All Rights Reserved (C) 2014 Sense Publishers

No part of this work may be reproduced, stored in a retrieval system, or transmitted in any form or by any means, electronic, mechanical, photocopying, microfilming, recording or otherwise, without written permission from the Publisher, with the exception of any material supplied specifically for the purpose of being entered and executed on a computer system, for exclusive use by the purchaser of the work. 


\section{ADVANCE PRAISE \\ Trayvon Martin, Race, and American Justice: Writing Wrong}

The cold-blooded murder of Trayvon Martin cracked the world open once more, and this smart, comprehensive collection pursues every fissure and follows every fracture into the American heart of darkness. The presumption of innocence is encoded in law, but it's so much more: it's the generous assumption that we expect to find the best and not the worst in one another, and, indeed, in our students and in every proximate stranger. Black youth have an opposite experience, also encoded in law and practice and history and conjecture: they are alleged guilty until proven innocent. Trayvon Martin, Race, and American Justice: Writing Wrong strikes a perfect balance between rage and hope, and offers fresh perspectives on every page; its insights and lessons will be mined for years by teachers, parents, youth workers, and anyone concerned about the sorry state we're in regarding the future of young men of color, and the pathways we might pursue toward enlightenment and liberation. This text is an invitation to a rebellion - the inevitable insurgency of Black youth brewing right now across the land as the descendants of enslaved workers step up to exercise their agency, and at that moment become agents of liberty and actors in history.

- William Ayers, Retired Distinguished Professor University of Illinois - Chicago

The murder of Trayvon Martin and acquittal of George Zimmerman serves as a crucible for interrogating how race works in today's post-civil rights era. Working from diverse perspectives, the authors in Trayvon Martin, Race, and American Justice: Writing Wrong offer incisive and vivid examinations of the contours of white supremacy today, inviting readers into a much-needed discussion of moral questions surrounding the very foundation life in the U.S.

- Christine Sleeter, Professor Emerita, California State University Monterey

"Trayvon Martin, Race, and American Justice: Writing Wrong is a powerful assemblage of voices that speak to the salience of race, gender, and their intersection. Collectively, the authors provide us with poignant reminders of the multiple forces that rail against Black males in our society. Each chapter grabs our attention, ignites our activism, and encourages us to remain steadfast in the struggle toward a true democracy for all Americans - a society where Black males' lives are valued and they no longer face daily threats to their humanity."

- Yolanda Sealey-Ruiz, Assistant Professor, Teachers College, Columbia University

"While motivated by Trayvon Martin's unfortunate and tragic death, this impressive collection serves as a one-of-a-kind tribute to Martin and will help to keep his legacy alive. The contributions are evocative and accessible, and while the focus is on Martin, the contributions also call attention to mundane, severe, and systemic racial wrongdoings, biases in existing research, colorblindness and white privilege, and erasures of history and failures of memory." - Tony E. Adams, Professor at Northeastern Illinois University and NCA book award winner 


\title{
CYNTHIA LEE
}

\section{DENYING THE SIGNIFICANCE OF RACE}

\author{
Colorblindness and the Zimmerman Trial
}

On February 26, 2012, at approximately 7:17 p.m., George Zimmerman spotted a young Black male in a hoodie walking in his neighborhood (Barry, 2012). Zimmerman thought the person looked suspicious, so he followed him and called 911. Within minutes of the 911 call, George Zimmerman and Trayvon Martin found themselves in a heated scuffle that ended when Zimmerman shot and killed Martin (Sanford Police Department [SPD] Offense Report, 2012). After being interviewed by police about the shooting, Zimmerman was released without arrest, causing a firestorm of protests across the nation (Wiggins, 2012a, 2012b). Eventually, Zimmerman was arrested and charged with murder in the second degree (Horwitz, 2012; Lawson, 2012).

Even though the initial failure to arrest Zimmerman focused the nation's attention on race and the criminal justice system, the trial in 2013 was nearly devoid of any mention of race. The judge ruled early on that the prosecution could use the term "profiling" but not "racial profiling" when describing Zimmerman's acts. (RoigFranzia, 2013; Muskal, 2013; Lucas \& Siemaszko, 2013). Zimmerman's attorney Mark O'Mara maintained during and after the trial that the case had nothing to do with race (Anderson, 2013). After the trial, Angela Corey, the prosecutor responsible for charging Zimmerman with second degree murder, told the press, "This case has never been about race..." (Winter, Novogrod, \& Arkin, 2013, p. 3). With the judge, prosecution, and defense in agreement that race was irrelevant, it is not surprising that the jury also thought the case had nothing to do with race (Cooper, 2013).

Why were the legal decision-makers in the Zimmerman case so eager to deny the significance of race? I surmise they either sincerely believed the case had nothing to do with race or thought it improper or disadvantageous to acknowledge that race was relevant. It is likely that the judge sincerely believed the color of one's skin was irrelevant and that it would be bad to acknowledge race. The judge tried to run a colorblind trial because she thought ignoring race was the fairest way to proceed.

The prosecution and defense may have also sincerely believed race was irrelevant. It is also possible they chose to proceed as though race was not relevant for strategic reasons. The public protests over the Sanford Police Department's initial failure to arrest stemmed from a belief that the decision not to arrest was racially biased (Lee, 2013). The defense did not want the jury to focus on the possibility that Zimmerman may have thought Martin looked suspicious because he was a young Black male. 


\section{LEE}

At the same time the defense team was claiming race was irrelevant, they also tried to use race to their advantage. At trial, they called a white woman who lived in Zimmerman's neighborhood to testify about being burglarized by a Black man, perhaps hoping that her testimony combined with racial stereotypes about Blacks as criminals might lead the jury to conclude that it was not completely unreasonable for Zimmerman to have thought Martin, a Black male, looked suspicious. They also argued that their client was selected for prosecution because of his race. O'Mara told the press that Zimmerman would not have been prosecuted if he had been Black, and accused Martin's supporters of turning the case into a civil rights matter (Real Clear Politics, 2013).

The prosecution had other motivations for denying the significance of race at Zimmerman's trial. They did not want the jury to think they were "playing the race card" or impermissibly relying on race. This rhetoric is used to suggest that one claiming racial discrimination or racial bias is lying or mistaken (Ford, 2008).

In an effort to avoid being perceived as trying to gain an improper advantage by arguing race, the prosecution adopted an overtly colorblind trial strategy. At the hearing on whether the prosecution would be allowed to use the term "profiling," the State assured the judge that the word "profiling" was not a racially charged term unless one made it so, and that they had no intention of making the term a racially charged one (Roig-Franzia, 2013). The prosecution then proceeded to argue the case without any explicit references to race.

Even as it tried to present a colorblind front, it appears that the prosecution actually believed race was important. Prosecutors used six or seven of their ten peremptory challenges to strike white females from the jury, prompting the defense to raise a Batson objection (Smerconish, 2013a, 2013b), a claim that the opposing party is impermissibly relying on race in the exercise of their peremptory challenges (Batson v. Kentucky, 1986). The judge disallowed two of these challenges, in essence finding that the government had impermissibly discriminated on the basis of race and/or gender. Someone on the prosecution team thought race and gender mattered, or the team would not have tried so hard to keep white women off the jury.

During rebuttal closing argument, prosecutor John Guy told jurors,

Race. This case is not about race. It's about right and wrong. ... Ask yourselves, all things being equal, if the roles were reversed and it was 28 year old George Zimmerman walking home in the rain with a hoodie on to protect himself from the rain, walking through that neighborhood, and a 17 year old driving around in a car who called the police ... [a]nd if it was Trayvon Martin who had shot and killed George Zimmerman, what would your verdict be? That's how you know it is not about race. (CrimeTimeVids, 2013)

Guy may have hoped his remarks would prompt jurors to think about whether racial stereotypes about African Americans had biased their perceptions in this case, but he never explicitly asked them to race-switch. He did not ask them to imagine a Black man following and confronting a White teenager in a hoodie, and then shooting the 
White teenager during a fistfight. Instead, Guy prefaced and concluded his remarks by telling jurors that the case was not about race, encouraging them to believe that race did not matter and that they should continue to view the case through colorblind eyes. Ultimately, not only did the government fail to secure a guilty verdict on seconddegree murder, it failed to secure a conviction on the lesser offense of manslaughter.

I suggest that the prosecution should have acknowledged, rather than denied, the significance of race. Explaining how racial stereotypes may have influenced not only Zimmerman's perception that Martin was a suspicious character, but also the jurors' own perceptions regarding the reasonableness of Zimmerman's fear, might may have encouraged the jury to think about the case more critically. The problem is that the prosecution team thought being colorblind was the proper way to proceed.

Once a tenet of liberalism, the ideology of colorblindness has become a mantra embraced by liberals and conservatives alike. Conservatives, however, use colorblindness to argue for strict scrutiny of all racial classifications, including those that seek to address past discrimination. We are encouraged not only to be colorblind; we are discouraged from acknowledging racial difference. Under the new ideology of colorblindness, anyone who pays attention to race is a racist (Cho, 2009). The good person, according to colorblind ideology, is blind to racial difference (Gotanda, 1991).

The ideology of colorblindness fails to acknowledge the reality of racial difference in today's society. While we may aspire to live in a colorblind society, we are not yet there. Research on race and social cognition has demonstrated for decades that racial stereotypes affect our perceptions, often without our awareness or intent (Lawrence, 1987; Krieger, 1995).

One of the most entrenched stereotypes is the Black-as-Criminal stereotype, which links Blacks with violence, danger, and criminality (Lee, 1996, 2003). An early study by Duncan (1976) showed how this stereotype can influence perception. In this study, participants observed two men involved in a heated verbal altercation that ended when one man shoved the other man. When the person shoving was Black and the man being shoved was White, seventy-five percent of the participants thought the shove was "violent," while only six percent characterized it as "playing around." In contrast, when the person shoving was white and the man being shoved was Black, forty-two percent of the participants described the actions of the shover as "playing around" and only seventeen percent characterized the shove as "violent."

The 'Black-as-criminal' stereotype persists today (Lee, 2013). Many social science studies have demonstrated the tendency to associate Blacks with weapons. Payne $(2001,2006)$ found that individuals are quicker to detect guns in the hands of armed targets when primed with a Black face than with a white face (Payne, 2001, 2006). Correll et al. (2002) found that when shown pictures of Black and white men holding either a weapon or a harmless object, individuals will fire at armed Black targets more quickly than armed white targets. Individuals will also decide not to shoot an unarmed target more quickly if the target is white than if he is Black (Correll, et al., 2002). 
One might wonder how all of this research relates to the Zimmerman trial. According to police reports, at the time Zimmerman shot Martin, he was on the ground face up with Martin on top of him (SDP Investigation Report 2013; SDP Offense Report, 2013, SDP Witness Statement, 2013). Zimmerman told police that that after he tried to return to his car, Martin circled back, confronted Zimmerman, and threw the first punch (Robles \& Caputo, 2012). There was no evidence corroborating Zimmerman's account that Martin threw the first punch, but the judge permitted the defense to show the jury an animated version of the defense's version of the facts, depicting Martin throwing the first punch (Sterbenz, 2013). Zimmerman also told police that when he was on his back on the ground with Martin on top of him, Martin put his hand on Zimmerman's nose and mouth and screamed, "You're going to die tonight," leading Zimmerman to believe Martin intended to kill him (Lucas \& Siemaszko, 2013). Zimmerman said he shot Martin because he thought Martin was reaching for his gun. One might legitimately question whether Martin's race really mattered if the reason Zimmerman shot Martin was because he thought Martin was reaching for his gun and was about to kill him.

If individuals are more likely to view a shove as dangerous and violent when a Black male is doing the shoving, but see the same shove as playing around when done by a white man, they may also be more likely to view punches as violent and life-threatening when the person doing the punching is a Black male and the one being punched is not Black, even if they might see the same scenario as merely a fist-fight if the person doing the punching was white (Lee, 2013). If individuals are quicker to link Blacks with weapons, they may be more likely to find credible a defendant's claim that he thought a Black man was reaching for his gun than if the same claim were made against a white man (Lee, 2013).

Kelman (1981) pointed out that legal decision makers have a great deal of discretion in deciding whether to broadly or narrowly frame the issues. According to Kelman, if a court sees the defendant as culpable, it may engage in broad time framing. In contrast, if the court favors the defendant, it may engage in narrow time framing. Kelman illustrated his theory with State v. Decina (1956), a classic case found in many criminal law textbooks involving a man who had an epileptic seizure at the wheel, causing the deaths of four schoolchildren. Even though Decina was not acting voluntarily during his seizure, and thus arguably the prosecution could not prove that he engaged in a voluntary act that caused the social harm, the court broadened the time frame in order to find a voluntary act. The court saw Decina's act of getting into the car and turning on the ignition as the voluntary act that satisfied the actus reus requirement (Kelman, 1981 p. 140). In contrast, Kelman noted that in Martin v. State (1944), a different court reversed the conviction of a man charged with being drunk on a public highway. The Martin court said that the defendant did not voluntarily appear drunk in public because the police carried him from his home into the street. Kelman pointed out that the Martin court favored the defendant by focusing narrowly on what took place immediately preceding the defendant's arrest, when the court could have broadened the time-frame and considered Martin's voluntary acts that caused the police to be called in the first place. 
The jury in the Zimmerman case had the discretion to focus either narrowly or broadly on the events preceding the shooting. The defense focused the jury upon the events immediately preceding the shooting, favoring Zimmerman's claim of self-defense. Alternatively, the jury could have focused on Zimmerman's culpability in starting the conflict. The law of self-defense generally prohibits an "initial aggressor" from arguing self-defense (Burke, 2013; Ross, 2014; Mannheimer, 2012). Zimmerman was the one who started the encounter by following Martin and then confronting him, asking Martin to explain his presence in the neighborhood (CNN Library, 2013). Whether Zimmerman's acts were sufficient to make him the initial aggressor is another question, but the defense precluded the jury from considering this question by convincing the judge to refuse to issue a jury instruction on the initial aggressor rule (Burke, 2013; Ross, 2014).

It is difficult to assess whether a prosecution strategy that highlighted race would have changed the outcome. Recent empirical research, however, suggests that a race conscious trial strategy might have helped. This research shows that making race salient leads jurors to treat similarly situated defendants the same, whereas not making race salient results in unequal treatment. In several experiments, Sommers and Ellsworth $(2000,2001,2003)$ found that when mock jurors were merely aware of the defendant's race, but race was not otherwise highlighted, they would convict Black defendants at much higher rates than similarly situated white defendants. When the possibility of disparate treatment based on race was highlighted, the mock jurors treated similarly situated white and Black defendants the same (Sommers \& Ellsworth, 2000, 2001). This research on race salience indicates that highlighting the possibility of racially disparate treatment reminds individuals of their egalitarian commitments (Lee, 2013). If the Zimmerman jury had been given such a reminder, they might have been a little less likely to see the unarmed Martin as the aggressor and Zimmerman as a man who needed to shoot in order to defend his life.

\section{REFERENCES}

Barry, D. (2012, April 2). In the eye of the firestorm: In Florida, an intersection of tragedy, race and outrage. The New York Times, p. A1.

Batson v. Kentucky, 476 U.S. 79 (1986).

Burke, A. (2013, July 15). What you may not know about the Zimmerman verdict: The evolution of an instruction. HuffPost: Black Voices. Retrieved from http://www.huffingtonpost.com

Cho, S. (2009). Post-racialism. Iowa Law Review, 94, 1589-1649.

CNN Library. (2013, June 5). Trayvon Martin fast facts. Retrieved August 29, 2013, from http://www. cnn.com

Cooper, A. (Presenter). (2013, July 15). Anderson Cooper 360: Exclusive interview with Juror B-37; defense team reacts to juror interview [Television broadcast]. New York, NY: CNN.

Correll, J., Park B., Judd, C. M., \& Wittenbrink, B. (2002). The police officer's dilemma: Using ethnicity to disambiguate potentially threatening individuals. Journal of Personality and Social Psychology, 83, 1314-1329.

CrimeTimeVids. (July 12, 2013). Trayvon Martin: George Zimmerman trial closing arguments day 14 part 3 [Video file]. Retrieved from http://www.youtube.com

Duncan, B. L. (1976). Differential social perception and attribution of intergroup violence: Testing the lower limit of stereotyping of blacks. Journal of Personality and Social Psychology, 4, 590-598. 


\section{LEE}

Eberhardt, J. L., Goff, P. A., Purdie, V. J., \& Davies, P. G. (2004). Seeing black: Race, crime, and visual processing. Journal of Personality and Social Psychology, 87, 876-893.

Ford, R. T. (2008). The race card: How bluffing about bias makes race relations worse. New York, NY: Picador.

Gotanda, N. (1991). A critique of "Our constitution is color-blind." Stanford Law Review, 44, 1-69.

Horwitz, S. (2012, April 12). Charge filed in martin killing. The Washington Post, p. A1.

Kelman, M. (1981). Interpretive construction in the substantive criminal law. Stanford Law Review, 33 , 591-673.

Krieger, L. H. (1995). The content of our categories: A cognitive bias approach to discrimination and equal employment opportunity. Stanford Law Review, 47, 1161-1248.

Lawrence, C. R. (1987). The id, the ego, and equal protection: Reckoning with unconscious racism. Stanford Law Review, 39, 317-388.

Lawson, T. (2012). A Fresh cut in an old wound-A critical analysis of the Trayvon Martin killing: The public outcry, the prosecutor's discretion, and the stand your ground law. Florida Journal of Law and Public Policy, 23, 271-310.

Lee, C. (2003). Murder and the reasonable man: Passion and fear in the criminal courtroom. New York, NY: New York University Press.

Lee, C. (2013). Making race salient: Trayvon martin and implicit racial bias in a not yet post-racial society. North Carolina Law Review, 91, 1555-1612.

Lee, C. K. Y. (1996). Race and self-defense: Toward a normative conception of reasonableness. Minnesota Law Review, 81, 367-500.

LSUDVM. (2013, July 14). Angela Corey: Zimmerman trial was never about race or guns [Video file]. Retrieved from http://www.youtube.com

Lucas, L., \& Siemaszko, C. (2013, July 1). Trayvon Martin shooting: George Zimmerman claims teen told him 'You're going to die tonight' and jumped him in police interviews. New York Daily News. Retrieved from http://www.nydailynews.com

Lucas, L., \& Siemaszko, C. (2013, June 21). George Zimmerman's Trayvon Martin murder trial will not open with discussion of race. New York Daily News. Retrieved from http://www.nydailynews.com

Mannheimer, M. J. Z. (2012, March 26). Trayvon Martin and the initial aggressor issue. PrawfsBlawg. Retrieved from http://www.huffingtonpost.com

Martin v. State, 17 So.2d 427 (Ala. Ct. App. 1944).

Muskal, M. (2013, June 22). Judge in Zimmerman trial limits racial references. Los Angeles Times, p. A12.

Payne, B. K. (2001). Prejudice and perception: The role of automatic and controlled processes in misperceiving a weapon. Journal of Personality and Social Psychology, 81, 181-192.

Payne, B. K. (2006). Weapon bias: Split-second decisions and unintended stereotyping. Current Directions in Psychological Science, 15, 287-291.

Real Clear Politics. (July 14, 2013). Mark O'Mara: "If Zimmerman was black, he never would have been charged." Retrieved from http://www.realclearpolitics.com

Robles, F. \& Caputo, M. (2012, June 21). Tapes show Sanford police grew skeptical of Zimmerman's story. Miami Herald. Retrieved from http://www.miamiherald.com

Roig-Franzia, M. (2013, July 3). Race is playing minor part in Zimmerman prosecution. The Washington Post. p. Al.

Ross, J. (2014). The supreme court's invisible hand in George Zimmerman's trial for the murder of Trayvon Martin (manuscript on file with author).

Sanford Police Department. (2012, February 26). Witness Statement [Police report]. Retrieved from http://www.scribd.com

Sanford Police Department. (2012, February 27). Offense Report [Police report]. Retrieved from http:/! www.scribd.com

Sanford Police Department. (2012, March 13). Report of Investigation [Police report].

Smerconish, M. (2013a, August 3). Did gender, not race, decide Zimmerman verdict? Sun-Sentinel, p. $21 \mathrm{~A}$.

Smerconish, M. (2013b, August 3). Zimmerman, race and the all-female jury strategy. The Tampa Tribune, p. 21. 


\section{DENYING THE SIGNIFICANCE OF RACE}

Sommers, S. R., \& Ellsworth, P. C. (2000). Race in the courtroom: Perceptions of guilt and dispositional attributions. Personality and Social Psychology Bulletin, 26, 1367-1379.

Sommers, S. R., \& Ellsworth, P. C. (2001). White juror bias: An investigation of prejudice against Black defendants in the American courtroom. Psychology, Public Policy, and Law, 7, 201-229.

Sommers, S. R., \& Ellsworth, P. C. (2003). How much do we really know about race and juries? A review of social science theory and research. Chicago-Kent Law Review, 78, 997-1031.

Sommers, S. R., \& Ellsworth, P. C. (2009). "Race Salience" in juror decision-making: Misconceptions, clarifications, and unanswered questions Behavioral Sciences \& the Law, 27, 599-609.

Speakmymind02. (2013, July 16). Robert Zimmerman race profiteers [Video file]. Retrieved from http:// www.youtube.com

State v. Decina, 2 N.Y.2d 133 (1956).

Sterbenz, C. (2013, July 12). Zimmerman defense shows jury controversial 'avatar'-like animation. Business Insider. Retrieved from http://www.businessinsider.com

Van Susteren, G. [Presenter] (2013, July 16). Zimmerman brother: Case fit the business model of the "Race Profiteers" [Video file]. New York, NY: Fox News. Retrieved from http://nation.foxnews.com Wiggins, O. (2012a, March 25). A rallying cry for justice in teen's death. The Washington Post, p. A3.

Wiggins, O. (2012b, April 1). NAACP leads march on Sanford. The Washington Post, p. A3.

Winter, T., Novogrod, J., \& Arkin, D. (2013, October 19). Zimmerman will likely get his gun back, if he requests it. NBC News. Retrieved from http://usnews.nbcnews.com 